Фармакологічні дослідження біологічно активних речовин Pharmacological researches of biologically active substances

Рекомендована д. мед. наук, профр. С. І. Климнюком

УДК 615.453.6:615.322:615.281.8

DOI

\title{
ВИВЧЕННЯ ПРОТИВІРУСНОЇ АКТИВНОСТІ ТАБЛЕТОК АЛЬТАБОР
}

\author{
(сС. Л. Рибалко ${ }^{1}$, Т. В. Крутських ${ }^{2}$, А. С. Шаламай ${ }^{3}$ \\ Інститут епідеміології та інфрекційних хвороб імені Л. В. Громашевського Академії \\ медичних наук України ${ }^{1}$, Київ \\ Національний фрармацевтичний університет², Харків \\ ПАТ НВЦ «Борщагівський ХФЗ» ${ }^{3}$, Київ
}

Резюме: вивчено противірусну активність таблеток Альтабор. Визначено, що препарат проявляє протигрипозну активністю та пригнічує репродукцію вірусу Епштейна-Барр.

Ключові слова: альтабор, противірусна активність, грип, вірус Епштейна-Барр.

Вступ. Сьогодні різні захворювання вірусної етіології становлять серйозну проблему для охорони здоров'я всіх країн. Послідовний розвиток діагностики гепатиту В (в 70-ті роки), ВІЛ-інфекції (в 80-ті), гепатиту С та герпесу (в 90-ті роки) продемонстрував розповсюдження цих захворювань у всьому світі.

Серед всіх інфекційних захворювань грип та ГРВІ займають перше місце за частотою та кількістю випадків в світі і складають 95 \%. За даними ВООЗ грипом та грипоподібними захворюваннями у світі хворіє 5 - 30 \% населення, що складає до 500 млн чоловік $[1,2]$. В Україні щорічно фріксують від 11 до 15 млн випадків захворювання на грип та ГРВІ [3, 4]. За 400 років в світі зареєстровано більш 100 епідемій та 18 пандемій грипу, які призвели до десятків мільйонів смертей [1]. Сьогодні втрати від глобальних епідемій грипу значно поступаються масштабам минулих пандемій завдяки можливості сучасної діагностики вірусу, наявності противірусних та антибактеріальних препаратів і покращенню медичного обслуговування населення. Але проблема лікування захворювання все ж залишається актуальною.

На фроні гострих вірусних іноекцій віруси герпесу можна сказати і непомітні, але не менш загрозливі. Герпес вперше був зафріксований за тисячу років до нашої ери, але проблемою, яка привертає до себе увагу, став тільки в XX столітті, після появи ВІЛ. На сьогодні відкрито більш 80 представників сімейства вірусів герпесу, з яких 8 типів патогенні для людини $[5,6]$. Одним 3 патогенних типів $€$ вірус ЕпштейнаБарр, до якого, за даними сероепідеміологічних досліджень, антитіла виявляються у $95 \%$ населення. Сьогодні даному вірусу відводиться важлива роль у фрормуванні пухлинних клітин в організмі людини, що викликає необхідність в підвищенні уваги з боку медичного та фармацевтичного співтовариства.

Створення противірусних засобів є однією з найбільш складних задач хіміотерапії інфекцій. Пов'язано це $з$ тим, що віруси, що містять РНК- і ДНК-складові, $€$ облігатними внутрішньоклітинними паразитами. В процесі розмноження віруси в основному застосовують апарат біосинтезу клітин макроорганізму, визначним чином модифікуючи його. В зв'язку з цим дуже важко знаходити вибірково діючі засоби, які б знешкоджували віруси не пошкоджуючи при цьому клітини «хазяїна» [7]. Тим не менш, за останні роки з'явились окремі противірусні препарати, які проявляють визначну вибіркову дію щодо заражених вірусом клітин і пригнічують реплікативний цикл вірусу. Одним 3 таких лікарських засобів є оригінальний вітчизняний препарат - таблетки Альтабор.

Мета роботи - дослідження з визначення противірусної активності таблеток Альтабор, а саме 3 вивчення їх впливу на репродукцію вірусів грипу та Епштейна-Барр.

Методи дослідження. Вивчення протигрипозної активності таблеток Альтабор проводили на моделі грипозної інфекції in vitro [8]. Для цього використовували культуру клітин MDCK (клітини нирки собаки, що перевивались). Подрібнену масу таблеток в дозах від 100 до 1,6 мкг/мл вносили до лунок планшетів, в яких вирощували клітини. Через 1 год в лунки, оброблені та необроблені препаратом, вносили вірус грипу в дозі 100 ІД $_{50}$. Через 72 год інкубації клітин при $37^{\circ} \mathrm{C}$ культуральну рідину збирали і в ній визначали активність гемаглютиніну та інфекційний титр вірусу грипу з подальшим титруванням на культурі клітин.

Дослідження впливу таблеток Альтабор на вірус Епшейна-Барр проводили в системі лімфобластоїднх клітин Raji інфікованих зазначеним вірусом. Культури клітин Raji являють собою В-лімфоцити людини, які трансформовані ВЕБ і містять в складі клітинної ДНК 63 копії вірусного геному на клітину, але ніколи не продукують віріони. Культуру клітин вирощували в 24 лункових планшетах для суспензійних культур в середовищі, яке містить 90 \% RPMI

ISSN 2312-0967. Pharmaceutical review. 2015. № 3 
Фармакологічні дослідження біологічно активних речовин Pharmacological researches of biologically active substances

1640, 10 \% ембріональної телячої сироватки і антибіотиків при $37{ }^{\circ} \mathrm{C} 35 \% \mathrm{CO}_{2}$. Для суперінфрікування лімфобластоїдних клітин використовували вірусний препарат, отриманий з супернатанта клітин В 95-8 (ці клітини продукують вірус) в концентрації 0,150 мкл на 1 млн клітин Raji.

Антивірусну активність альтабору вивчали 3 використанням концентрації препарату 1000, 750, 500, $250,125,64,32,16,4,2,1,0,5,0,1$ мкг/мл при його внесенні відразу після інфрікування клітин вірусом Епштейна-Барр. Максимально переносиму концентрацію визначали за пригніченням життєздатності клітин (метод підрахунку живих та мертвих клітин при забарвленні 0,1 \% трипановим синім, а також альтернативним методом 3 використанням препарату МТТ. Трипановий синій застосовується для детекції мертвих клітин при їх огляді в мікроскопі. Цей барвник має властивість проникати крізь мембрану мертвих клітин, при цьому живі клітини залишаються інтактними до нього. Застосування препарату МТТ 3-(4,5-диметилтіазол-2-іл) дифенілтетрозоліум бромід) засновано на тому, що нормально функціонуюча дегідрогеназна система мітохондрій інтактних клітин перетравлює МТТ як штучний субстрат в формазан, в свою чергу, може бути зафріксований спектрофотометрично. Перетворення МТТ в формазан значно дозозалежно зменшується при загибелі клітин під впливом вірусу або досліджуваних токсичних для клітин речовин. Результат аналізу визначався спектрофротометрично на ридері «Dynatech» (Швеція) при довжині хвилі 540 нм.

Результати й обговорення. Протигрипозна активність таблеток Альтабор ґрунтується на інгібуванні вірусної нейрамінідази, фермента, який відповідає за здатність вірусного віріону проникати в клітину хазяїна і виходити 3 неї після розмноження [9, 10]. Результати проведених досліджень 3 вивчення протигрипозної активності таблеток Альтабор наведено в таблиці 1.

Аналіз наведених даних свідчить, що таблетки Альтабор активно інгібують репродукцію вірусу грипу в дозах від 100 до 6,75 мкг/мл на 7,5-3,0 lg ІД
Таблиця 1. Вплив таблеток Альтабор на вірус грипу

\begin{tabular}{|c|c|c|c|}
\hline $\begin{array}{c}\text { Доза в } \\
\text { мкг/мл }\end{array}$ & $\begin{array}{c}\text { Титр гема- } \\
\text { глютинінів } \\
\text { у РГА }\end{array}$ & $\begin{array}{c}\text { Інсрекційний } \\
\text { титр вірусу в } \\
\text { Ig І }\end{array}$ & $\begin{array}{c}\text { Показник } \\
\text { інгібіювання } \\
\text { Ig І }\end{array}$ \\
\hline 100 & - & 0 & 7,5 \\
\hline 50 & - & 0 & 7,5 \\
\hline 25 & 48 & 2,0 & 5,5 \\
\hline 12,5 & 1632 & 3,0 & 4,5 \\
\hline 6,75 & 6464 & 4,5 & 3,0 \\
\hline 3,37 & 128128 & 6,0 & 1,5 \\
\hline 1,6 & 128128 & 6,0 & 1,5 \\
\hline
\end{tabular}

що свідчить про виражену протигрипозну активність препарату.

щодо дослідження впливу таблеток Альтабор на вірус Епштейна-Барр, для визначення терапевтичного індексу препарату була визначена його максимально переносима концентрація. Вивчено рівень проліферації культури клітин Raji при внесенні речовин без інфрікування вірусом і з інфрікуванням. За результатами проведених досліджень було встановлено максимально переносиму концентрацію, яка склала - 750 мкг/мл. Репродукцію вірусу Епштейна-Барр під впливом таблеток Альтабор вивчали молекулярним методом шляхом визначення числа вірусних геномних еквівалентів на клітину методом ПЛР (полімеразна ланцюгова реакція) [11]. Визначено, що мінімально активна концентрація для препарату склала 0,1 мкг/мл. Виходячи зі значення максимально переносимої та мінімально активної концентрації, терапевтичний індекс таблеток Альтабор встановили на рівні 5000, що свідчить про виражений вплив препарату на репродукцію вірусу.

Висновки. Результати проведених досліджень 3 вивчення антивірусної активності таблеток Альтабор встановили, що препарат має протигрипозну активність, активно інгібують репродукцію вірусу грипу в дозах від 100 до 6,75 мкг/мл на 7,5-3,0 lg ІД парат пригнічує репродукцію вірусу Епштейна-Барр, про що свідчить терапевтичний індекс таблеток Альтабор встановлений на рівні 5000.

\section{Список літератури}

1. Генетический анализ вируса гриппа A H1N1 "пандемический" в условиях эпидемии / Е. С. Костюкова, Н. Б. Захаржевская, П. А. Костин [и др.] // Терапевтический архив. - 2012. - № 3. - С. 48-54.

2. Гриневич О. Й. Огляд епідемічної ситуації у світі щодо захворюваності на сезонний і пташиний грип на початку 2012 року / О. Й. Гриневич, І. Г. Маркович // Сімейна медицина. - 2012. - № 1. - С. 32-34.

3. Голубка О. С. Оцінка ефективності системи дозорного епідеміологічного нагляду за грипом в Україні : автореф. ... канд. мед. наук, спец.: 14.02.02 епідеміологія / О. С. Голубка. - К. : ДУ "Ін-т епідеміології

та інфекційних хвороб ім. Л. В. Громашевського НАМН Укр.", 2013. - 20 с.

4. Маркович І. Г. Аналіз захворюваності на грип населення України за 2009-2013 роки / І. Г. Маркович, О. Й. Гриневич // Україна. Здоров'я нації. - 2013. - № 2. - C. $118-124$.

5. Исаков В. А. Герпесвирусные инфекции человека: руководство для врачей / В. А. Исаков, Е. И. Архипова. - СПб. : СпецЛит., 2006. - 303 с

6. Хахалин Л.Н. Герпесвирусные заболевания человека [Электронный ресурс] / Л. Н. Хахалин, Е. В. Соловьева. - Режим доступа: http://www.clinpharma.com/magazine/

ISSN 2312-0967. Фармацевтичний часопис. 2015. № 3 
Фармакологічні дослідження біологічно активних речовин

Pharmacological researches of biologically active substances

journal5/gerp1.htm

7. Жаркова Л. Д. Молекулярно-біологічна основа адаптації вірусів грипу A (H1N1) та A (H3N2) до нового хазяїна та нові вітчизняні антигрипозні препарати : авторефр. .... канд. біолог. наук, спец.: 03.00.06 -вірусологія / Л. Д. Жаркова. - К. : НАН Укр. Ін-т мікробіології та вірусології ім. Д. К. Заболотного, 2012. - 23 с.

8. Доклінічні дослідження лікарських засобів : метод. реком. / за ред..: чл..-кор. АМН України О. В. Стефранова. - К. : Авіцена, 2001. - 528 с.

9. Обертинська О. В. Сучасна етіотропна терапія грипу інгібіторами нейрамінідази / О.В.Обертинська //
Сімейна медицина. - 2014. - № 1. - С. 111-114.

10. Пат. на винахід 99317 Україна, МПК А61К 36/18, А61K 9/20, А61P 31/12, Фармацевтична композиція у формі таблеток для лікування вірусних захворювань / Тищенко Р. О., Кобилинська В. І., Крутских Т. В., Безпалько Л. В., Сова Є. О., Шаламай А. С.; - № а201007829; заявл. 22.06.2010; опубл. 10.08.2012, Бюл. № 15.

11. Киселев О. И. Герпесвирусные инфекции: лекарственные препараты и ПЦР-мониторинг терапии [Электронный ресурс] / О. И. Киселев, Г. Р. Виноградская, М. А. Струкова. - Режим доступа: http://www.influenza. spb.ru/Herpes/book/herpes.htm.

\section{ИЗУЧЕНИЕ ПРОТИВОВИРУСНОЙ АКТИВНОСТИ ТАБЛЕТОК АЛЬТАБОР}

\section{С. Л. Рыбалко, Т. В. Крутских², А. С. Шаламай}

Институт эпидемиологии и инфрекционных болезней имени Л. В. Громашевского Академии медицинских наук Украины ${ }^{1}$, Киев

Национальный фрармацевтический университет², Харьков

ПАО НПЦ «Борщаговский ХФЗ» ${ }^{3}$, Киев

Резюме: изучена противовирусная активность таблеток Альтабор. Определено, что препарат обладает противогриппозной активностью и подавляет репродукцию вируса Эпштейна-Барр.

Ключевые слова: альтабор, противовирусная активность, грипп, вирус Эпштейна-Барр.

\section{STUDY OF ANTIVIRAL ACTIVITY OF TABLETS ALTABOR}

\section{S. L. Rybalko ${ }^{1}$, T. V. Krutskykh², A. S. Shalamay ${ }^{3}$}

Institute of Epidemiology and Infectious Diseases by L. V. Hromashevskyi of Academy of Medical Sciences of Ukraine ${ }^{1}$, Kyiv

National University of Pharmacy², Kharkiv

JSC SIC "Borshchahivka CPP"3, Kyiv

Summary: there was studied antiviral activity of tablets Altabor. It was determined that the drug has antiviral activity and inhibits the reproduction of Epstein-Barr virus.

Key words: altabor, antiviral activity, influenza, Epstein-Barr virus. 